\title{
MEDICAL STUDENTS ENCOUNTER WITH VICTIMS OF VIOLENCE: A SIMULATION PROGRAM
}

\author{
SEVGI TURAN
}

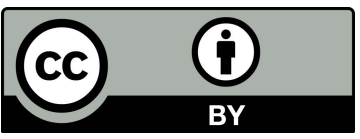

Associate Professor, Hacettepe University Faculty of Medicine, Department of Medical Education and Informatics, Sihhiye, 06100 Ankara, Turkey E-mail address: sevgigunalturan@gmail.com

\section{MELIH ELÇIN}

Professor, Hacettepe University Faculty of Medicine, Department of Medical Education and Informatics,

Sihhiye, 06100 Ankara, Turkey

E-mail address: melcin@gmail.com

\section{ORHAN ODABAŞI}

Associate Professor, Hacettepe University Faculty of Medicine,

Department of Medical Education and Informatics, Sihhiye, 06100 Ankara, Turkey

E-mail address: odabasi@hacettepe.edu.tr

\section{MÜGE DEMIR}

Lecturer, Hacettepe University Faculty of Medicine, Department of History of Medicine and Medical Ethics,

Sihhiye, 06100 Ankara, Turkey

E-mail address: mdemir@hacettepe.edu.tr

\section{NÜKET ÖRNEK BÜKEN}

Professor, Hacettepe University Faculty of Medicine, Department of History of Medicine and Medical Ethics,

Sthhiye, 06100 Ankara, Turkey

E-mail address: nuketbuken@hotmail.com

\begin{abstract}
Violence against women is a serious violation of women's human rights and a significant health issue in many countries. As domestic violence is a subject of high concern in the different countries, there has been considerable research into the topic of domestic violence generally, though comparatively less is known on health care pro-
\end{abstract}


viders roles related to domestic violence. Health care providers are usually frontline professionals that victims of violence get in touch with, even sometimes not explicitly. Therefore, health care providers' skills and attitudes are very important when giving a hand to victims of violence professionally.

A special case is Turkey. Where the social structure in Belgium, England and Austria is of an matriarchal nature (in a sociological sense, not anthropologic), Turkey is strongly patriarchally ordered. Moreover, it has a higher level of social acceptance of domestic violence.

This paper describes the program in a medical curriculum on violence against women. Simulation which is increasingly being used in health care workers training is used to deliver the program. Standardized patient (SP) methodology is the preferred modality of simulation. SP is a lay person trained to portray a patient in order to simulate a set of symptoms or problems. SPs would have first-hand knowledge, experience and feedback to improve the skills. The simulation program and the experiences of the students acquired during this program are discussed in this paper.

Key words: training program, violence against women, medical education

\section{INTRODUCTION}

Violence against women is a violation of human rights. It affects physical, sexual and mental health of women, in some cases causing death. According to the United Nations Declaration on Elimination of Violence Against Women, it is defined as 'any act of violence that results in or is likely to result in, physical, sexual or psychological harm or suffering to women, including threats of such acts, coercion or arbitrary deprivation of liberty, whether occurring in public or private life' (The state of world population, 1997). The Istanbul Convention (Council of Europe Convention on preventing and combating violence against women and domestic violence) (CETS, 210, 2011) was confirmed in this definition.

CEDAW (Convention on the Elimination of All Forms of Discrimination Against Women) also regarded violence against women as a human rights violation, and included the recommendations. CEDAW, to which Turkey was a party in 1985, indicated the states' responsibility to respect, protect and fulfill for elimination of all forms of discrimination against women. Despite all the precautions, the National Survey of Domestic Violence (2013) in Turkey showed that women were still suffering from violence within their family, and $36 \%$ of them were exposed to physical violence.

In Turkey, the gender roles attributed to women are unquestionably accepted and internalized by the society as well as in other similar societies. The health status of women depends on women's social status. Although women in Turkey have relatively equal legal rights, they face inequalities in both public and private spheres. Violence against women creates situations that interfere with, violate or devalue women's human rights and their ability to benefit from their basic freedoms. Protecting these rights and freedoms has not been successful in the past and the need to do so is becoming more widespread. 
When we question where the strength of the violence comes from, how it is nourished from a societal base, and why it has not been overcome over thousands of years, we encounter the concept of patriarchy. Patriarchy, which became established over a long period of time, is fed by various kinds of power and, in renewing itself today, is strengthened and still evident in our society. It can be said that a society has become militarized when it has come to the point where images, conceptions and feelings based on violence are disseminated throughout that society, yet conflict cannot be solved by relying on weapon power (Buken, \& Sahinoğlu, 2006).

Although patriarchal structures include cultural differences according to historical period and specific societies, it is possible to witness the similarities in various societies, institutions and relationships. Medical science, which has existed for centuries as an institutional structure more than an occupation, had also perpetuated patriarchy. Inside the institutional structure of medical sciences, we can use the concept of patriarchy in general to explain the late appearance of women in the field of medical science and to explain the relationships between doctors and nurses. The behavior and attitudes of doctors towards patients through the process of diagnosis and treatment can also be viewed from the standpoint of patriarchy (Buken, \& Sahinoğlu, 2006).

When violence against women is discussed in health care situations, the first thing that comes to mind is the access to health care facilities of women who have met with violence and how health care professionals should behave towards them. A number of issues pose themselves as questions that may not have immediate answers:

In our country, should we have physicians responsible for treating only women who have met with violence, or should health care professionals working in facilities that those women can easily access have additional responsibilities?

What is the attitude of physicians and health care workers who encounter a woman who has experienced violence and what should it be? Sometimes health care workers can inflict more hurt on women who have experienced violence by not asking relevant questions, by not taking an appropriate history about rape and sexual violence, by not creating an examination environment that is supportive. Health care providers are usually frontline professionals that victims of violence get in touch with, even sometimes not explicitly. Therefore, health care providers' skills and attitudes are very important to give a hand to the victims of violence professionally. Health care providers should learn how to talk to women about violence, offering help to the victims. They should respond to the physical, emotional, and security needs of women, and provide medical treatment, offer counseling, document injuries, and refer women to legal assistance and support services. But health care providers often do not have appropriate skills to recognize victims of violence, communicate with them, and help them. This paper describes the program in a medical curriculum on violence against women. 


\section{THE Simulation PROGRAM FOR VIOLENCE AGAINST WOMEN}

The program was conducted with third year students at Hacettepe University Faculty of Medicine. Simulation, which is increasingly being used in health care worker training, is used to deliver the program. Simulation as a method of instruction and structure of the program are explained in the following sections.

\section{THE PLACE OF SIMULATION IN MEDICAL ENCOUNTERING}

Simulation is widely used in training of health sciences professionals. Simulation is also used in training of airline pilots, business, law and management training (de Jong, Lane, \& Sharp, 2012). Key characteristics of real events, situations or procedures are imitated in simulation (Girod, \& Girod, 2008). It can close the gap between the classroom and the real world as it creates real life-like environments (Cruickshank, \& Metcalf, 1993). Tasks, relationships, behavior, some cognitive activities, phenomenon or equipment can be simulated.

The most important motive for the wide use of simulation in health sciences education is safety. Novice trainees can safely practice and improve their skills with simulation methods which provide a risk free environment (de Jong, Lane, \& Sharp, 2012). Therefore, when the real events are dangerous, expensive or potentially harmful, simulation is preferred. While experiencing in real health environment, ethical problems could also occur. Before practicing on patients, learners are expected to be prepared at acceptable levels (Ker, \& Bradley, 2010).

Simulations can be used for both instruction and assessment purposes. A wide range of simulation techniques and approaches is applicable to learners at all levels. A continuum from low to high levels of fidelity and from low to high levels of authenticity have been used successfully for many years (Ker\&Bradley, 2010). Manikins, computer-assisted resources or simulated patients/persons can be used as the simulation modalities in medical education. Simulations can also be conducted using videos, role-playing experiences, card games, and computer based activities (Girod, \& Girod, 2006).

Simulation can improve technical and non-technical skills. Instead of the traditional apprenticeship model, simulation offers a feasible alternative for learning procedural skills and the opportunity to rehearse performance in complex integrated scenarios in a safe, protected, learner-centered simulated clinical setting (Ker, \& Bradley, 2010).

Simulated patients may be usefully involved in simulated health care environments. The Simulated patient is ' $a$ well person trained to simulate a patient's illness in a standardized way" (Barrows, 1993). Ker and Bradley (2010) described simulated patients in a more extensive framework: an SP is a person without a history or physical signs who is trained to portray a role and/or mimic particular physical signs for the purposes of teaching or assessment. SPs can attend 
the teaching and assessment of physical examination, procedural skills, communication and consultation.

Simulation is useful for achieving experience and competence in complex situations. It can be used in training of physicians both to improve their ability to communicate and take history in violation cases and to develop students' sensitivity to violence against women. An on-going program focused on medical students' professional skills, and the integration of domestic violence in this program is explained in the following section.

\section{STRUCTURE OF THE PROGRAM}

Communication skills training is the main component of the "Good Medical Practice" program at Hacettepe University Faculty of Medicine. The "Good Medical Practice" program was initiated in 2004. Good Medical Practice is a comprehensive program designed on the communication skills training base, supported by related topics of clinical skills-physical examination training, medical humanities, ethics and professionalism, evidence based medicine and clinical visits. The aim of the program is to achieve the students' skills and attitudes needed by a good physician who is competent in caring for and communicating with patients (Elçin, et al. 2010; Elçin, et al. 2014).

Good Medical Practice is an integrated 3-year program that is designed on the basis of spiral curriculum nature. Students have encounters with SPs in communication skills part of the program throughout preclinical years in the following sequence:

- $\quad$ First year: Basics of medical encounter and patient history taking

- Second year: Patient history taking and difficult patients

- Third year: Breaking bad news, physical examination, clinical ethical context.

The communication skills training section takes 12 to 15 hours of the program which is in total 104 hours each year. The steps of the communication skills training are:

16. First session: The theoretical base of patient encountering is discussed. Students also watch a film about patient encounter and discuss it.

17. Second session: Students participate in an encounter with a SP for up to 10 minutes in a simulated environment. All encounters are archived digitally.

18. Third session: It is the debriefing session. Students discuss the general principles of medical encounter, watch their captured videos, discuss their encounters and get feedback.

19. Fourth session: Students have their second encounter with an SP up to 10 minutes in a simulated environment.

20. Fifth session: It is the second debriefing session. Students watch their second performances and get feedback. 
All encounters are stored in the digital archives. Students participate in an Objective Structured Clinical Examination (OSCE) each year for the assessment step of the program.

Third-year students have two more sessions: encounters with clinical ethical context. Clinical ethical encounters consist of four scenarios: clinical ethics, termination of treatment, sharing of health resources, and domestic violence. Students do not know which SP (scenario) they will encounter in that session. All scenarios are discussed in the briefing sessions.

SPs are trained to portray a real patient in order to simulate a set of symptoms or problems of victims of violence. SPs have first-hand knowledge and experience to give feedback for improving students' communication and consultation skills. Four female SPs are trained for domestic violence encounters, and they have refreshment training at the beginning of the each academic year. The scenario used in those encounters is: A 40-year-old married woman experienced a physical abuse by her husband, comes in the outpatient clinic. She tells that she slipped and fell down in her kitchen, and hit her head on the cupboard. She forces the physician to order a head radiography. She refuses physical examination, and does not answer any of the questions related with abuse.

The domestic violence theme was implemented into the Good Medical Practice program in 2009-2010 academic year and almost 1000 students have participated in these sessions up to June 2016.

\section{CONCLUSION}

The first small steps have been taken to educate health care professionals and increase their awareness on this issue. It is very encouraging that the medical schools and other medical societies have begun to include important agenda items for their curriculum on the attitude of physicians towards violence against women. It is necessary for the medical profession to acquire an attitude to care that is gender sensitive and to recognize the importance of the approach taken by health care workers to violence against women (Buken, \& Sahinoğlu, 2006).

In particular, in specialties such as emergency services, forensic medicine, and obstetrics and gynecology, it is necessary to update continuing education on this subject. It is necessary to educate physicians before and after graduation about their approach to women who have experienced sexual violence. The patient's history, physical examination and treatment process should be evaluated again so that care that strengthens the woman is given, and psychological support must not be forgotten.

An important achievement in physicians' training led by using simulation is the prevention of harm to both patients and students; it provides a safe educational environment. Students can make mistakes, learn from their mistakes, and try again. A safe educational environment is more essential when the fragility of victims of violence is considered. On the other hand, medical students 
are expected to become competent professionals until graduation. We experienced that simulation methods can be utilized as a powerful learning method to create real-life like environments to achieve competence.

\section{REFERENCES}

1. Barrows, H.S. (1993). An overview of the uses of standardized patients for teaching and evaluating clinical skills. Academic Medicine, 68, 443-451.

2. Buken, N.O., \& Şahinoğlu, S. (2006). Violence Against Women In Turkey and The Role of Women Physicians. Nursing Ethics, 13(2), 197-205.

3. CEDAW (Convention on the Elimination of All Forms of Discrimination Against Women). Retrieved August 8, 2016, from: http://www.un.org/womenwatch/daw/cedaw/text/econvention.htm

4. CETS (2011). İstanbul Convention. Council of Europe Convention on preventing and combating violence against women and domestic violence, Retrieved August 8, 2016, from https:/ / rm.coe.int/CoERMPublicCommonSearchServices/DisplayDCTMContent?documentId= $090000168008482 \mathrm{e}$

5. Cruickshank, D.R., \& Metcalf, K.K. (1993). Improving pre-service teacher assessment through on-campus laboratory experiences. Theory into Practice, 32(2), 86-92.

6. De Jong, T., Lane, J., \& Sharp, S. (2012). The efficacy of simulation as a pedagogy in facilitating pre-service teachers' learning about emotional self-regulation and its relevance to the teaching profession. Australian Journal of Teacher Education, 37(3), 34-43.

7. Elçin, M., Odabaşı, O., Turan, S., Sincan, M., \& Başusta, N.B. (2010). Tıp Eğitiminde İletişim Becerilerinin Standart Hastalar ve Yapılandırılmış Değerlendirmelerle Geliştirilmesi [Development of Communication Skills Training in Medical Education through standardised Patient and Structured Evaluation]. Hacettepe Tip Dergisi, 41, 219-230.

8. Elçin, M., Turan, S., Odabaşı, O., Abay, E., Onan, A., \& Sezer, B. (2014). İyi Hekimlik Uygulamaları. 11. Baskı [Good Medical Practice. 11th Edition]. Ankara: Hacettepe Üniversitesi Basımevi.

9. Girod, M., \& Girod, G.R. (2008). Simulation and the need for practice in teacher preparation. Journal of Technology and Teacher Education, 16(3), 307-337.

10. Kadına Yönelik Şiddetle Mücadele Ulusal Eylem Planı 2012-2015. Aile ve Sosyal Politikalar Bakanlığı Kadının Statüsü Genel Müdürlüğü [Action Plan for Violence to Women 2012-2015. Ministery ofFamily andSocialPolicy,DirectorateGeneralofWomenStatus].Retrieved August8, 2016, from http://bianet.org/files/doc_files/000/000/643/original/kadina_yonelik_siddet _uep12-15.pdf

11. United Nations Fund for Population Activities (1997). The State of World Population, 43-44. 